
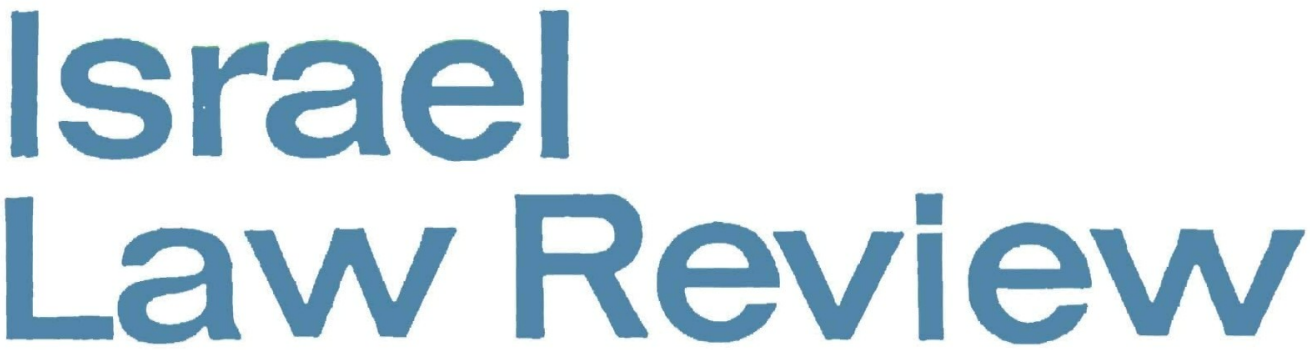

\title{
SYMPOSIUM ON LEGAL ETHICS
}

Shalev Ginossar 1 The Lawyer's Divided LoyaltiesIntroductory Note

Michele Taruffo 5 The Lawyer's Role and the Models of Civil Process

Vittorio Denti 20 Public Lawyers, Political Trials and the Neutrality of the Legat Profession

L. Ray Patterson 28 On Analyzing the Law of Legal Ethics:

An American Perspective

\section{ARTICLES}

S. Z. Feller

40 Concurrent Criminal Jurisdiction in the International Sphere

J. Lador-Lederer 75 Jewry's Nationals

NOTES

Alfred Witkon 103 Lord Denning and the British Steel Strike

S. Goldstein and

D. Cohen 110 Digest: Recent Legislation and Cases

Books

Frances Raday 127 W.B. Creighton, Working Women and the Law

Poter Elman 129 Kamenka and Erh-Soon Tay, eds., Justice 


\section{EDITORIAL BOARD}

Chairman - S. Goldstein
P. Elman
I. Englard
S. Ginossar
D. Kretzmer
A.V. Levontin
S. Shilo
G. Tedeschi
J. Weisman
U. Yadin
A. Yoran

Co-ordinating Editor - Stuart A. Wurtman

The Israel Law Review Association gratefully acknowledges the financial assistance of the following institutions:

The Faculty of Law, The Hebrew University of Jerusalem

The Ministry of Justice of Israel

The S.A. Schonbrunn Research Endowment Fund

Material for publication should be submitted to:

The Coordinating Editor,

Israel Law Review, c/o Faculty of Law, Hebrew University,

Mount Scopus, P.O.B. 24100, Jerusalem, Israel

For glossary and abbreviations see p. 3 of the cover.

(c) 1981

ISSN 0021-2237

Printed In Israel at Alpha Press, Jerusalem 